\title{
Opportunities to Study at the Max Planck Institutes in Germany
}

MARIE-LOUISE BERNAL

F OLLOWING THE tradition of many other members of the profession and of The International Association of Law Libraries, I spent the month of May 1993 in Hamburg, Germany, at the Max Planck Institute for Foreign and International Public Law as a scholarship recipient. It was such a rewarding experience both personally and professionally that I would encourage colleagues to consider this as a research option.

I was present during the brief time period when the directorship of the library of the Institute was split between the outgoing Director Dr. Ralph Lansky, who had held that position since the 7o's, and the incoming Director (and Deputy Director for many years) Dr. Jürgen C. Gödan, who was to take over as Director effective July I, I993. At the present time there are few other law librarians in Germany who can rival the experience and background of Drs. Lansky and Gödan. Both are superb examples of Renaissance men, balancing German legal research expertise with international law library cooperation. My mission was to survey the German law libraries and their new willingness to participate in the automation of worldwide legal information networking, and I needed to meet the major players in this field. As a result of their guidance and willingness to share their network of contacts, I was given access to library administrators at institutions in Berlin, Bonn, Karlsruhe, and Leipzig.

The Institute in Hamburg is one of six Max Planck research centers in Germany devoted to foreign and international law. The other ones are the Institute for Comparative Public Law and International Law in Heidelberg, the Institute for European Legal History in Frankfurt, the Institute for Foreign and International Criminal Law in Freiburg, and the two Institutes in Munich, one devoted to patent law, the other one to social law.

Judging from my experience in Hamburg, there are many advantages to being designated a visiting scholar at the Max Planck Institute. Depending upon availability, you may be able to reserve one of the guestrooms in the Institute building. In this self-contained facility are located the library, the 
faculty and the administration. Other benefits are a desk where you may utilize your computer, a key that allows all-hour access to the library, the right to use the photocopying machines (with some limitation), the chance to read daily newspapers from around the globe, and, last but not least, the opportunity to freely use and browse among the Institute's specialized collections. It was stimulating not only to meet the research staff of the Institute and colleagues working in its library, but also to be able to exchange ideas with visiting scholars from all over the world.

Applications for scholarship and permission to spend time at one of the Institutes can be obtained by writing directly to the particular Institute of your interest. Space is usually scarce and it normally takes a year of advance planning. Knowledge of German is not a requirement-but it will undoubtedly make the experience more worthwhile. I can highly recommend it! 